Article

\title{
The First Complete Mitochondrial Genome of the Flathead Cociella crocodilus (Scorpaeniformes: Platycephalidae) and the Phylogenetic Relationships within Scorpaeniformes Based on Whole Mitogenomes
}

\author{
Lei Cui ${ }^{1,+}$, Rongbo Cao ${ }^{1,+}$, Yuelei Dong ${ }^{1}$, Xingchen Gao ${ }^{2}$, Jingyi Cen ${ }^{1, *}$ and Songhui Lu ${ }^{1, *}$ \\ 1 Key Laboratory of Eutrophication and Red Tide Prevention, \\ Research Center for Harmful Algae and Marine Biology, Jinan University, Guangzhou 510632, China \\ 2 Chinese Sturgeon Research Institute, Three Gorges Corporation, Yichang 443100, China \\ * Correspondence: ps2sai@163.com (J.C.); lusonghui1963@163.com (S.L.); \\ Tel.: +86-20-8522-5913 (J.C.); +86-20-8522-2720 (S.L.) \\ + These authors contributed equally to this work.
}

Received: 21 May 2019; Accepted: 12 July 2019; Published: 15 July 2019

\begin{abstract}
Complete mitochondrial genomes (mitogenomes) are important molecular markers for understanding the phylogenetics of various species. Although recent studies on the mitogenomes of the Scorpaeniformes species have been greatly advanced, information regarding molecular studies and the taxonomic localization of Platycephalidae is still sparse. To further analyze the phylogeny of Platycephalidae, we sequenced the complete mitogenome of Cociella crocodilus of the Platycephalidae family within Scorpaeniformes for the first time. The mitogenome was 17,314 bp in length, contained two ribosomal RNA genes (rRNAs), 22 transfer RNA genes (tRNAs), 13 protein-coding genes (PCGs), and two typical noncoding control regions (the control region (CR) and origin of the light strand (OL)). All PCGs used standard initiation codons ATG, apart from cox1. The majority of the tRNA genes could be folded into cloverleaf secondary structures, whereas the secondary structure of tRNASer (AGN) lacked a dihydrouridine (DHU) stem. The CR contained several conserved sequence blocks (CSBs) and eight tandem repeats. In addition, the phylogenetic relationship based on the concatenated nucleotides sequences of 13 PCGs indicated that the Platycephalidae species are relatively basal in the phylogenetic relationships of Scorpaeniformes. Our results may not only advance the origin and the evolution of Scorpaeniformes, but also provide information for the genetic evolution and taxonomy of the teleostean species.
\end{abstract}

Keywords: mitochondrial genome; scorpaeniformes; platycephalidae; Cociella crocodilus; phylogenetic analysis

\section{Introduction}

Within the order of Scorpaeniformes, the Platycephalidae family is usually distributed in tropical and temperate coastal or estuarine waters in the Indian and Pacific Oceans. Most of the species live in typical sandy and muddy benthic habitats [1,2]. Platycephalidae, most of which have important commercial and medicinal value [3], consists of approximately 70 valid species of 17 genera [4]. The identification of flatheads usually depends on morphological characteristics such as an elongated body with a spiny depressed head and a large mouth [5]. With the development of molecular biology and molecular genetics, DNA markers (e.g., nuclear and mitochondrial genes) have been widely applied in studies of classification, phylogenetics and genetic diversity of fish. 
The typical mitochondrial genome (mitogenome) is a circular, double-stranded molecule, that ranges in size from $15 \mathrm{~kb}$ to $19 \mathrm{~kb}$, and generally contains 37 genes (13 protein-coding genes (PCGs), two ribosomal RNA genes (12S rRNA and 16S rRNA), 22 transfer RNA genes (tRNAs) and two noncoding regions (the control region $(\mathrm{CR})$ and origin of the light strand $\left(\mathrm{O}_{\mathrm{L}}\right)$ ), and has significant functions in the regulation and initiation of mitogenome transcription and replication $[6,7]$. In recent years, mitogenomes have been widely used as effective molecular markers for molecular evolution, phylogenetic studies and population genetics $[8,9]$ due to their unique characteristics of maternal inheritance, relatively conserved genome structures, coding content conservation, high mutation rate and low intermolecular genetic recombination level [6]. Based on these advantages, the complete mitogenome of genetic code alteration, gene rearrangement, secondary structures of tRNAs and regions of transcription and replication are also widely utilized for taxonomic phylogenetic analysis [10,11].

To date, complete mitogenomes have been sequenced for approximately 39 Scorpaeniformes species. However, only one complete mitogenome from Platycephalidae, Platycephalus indicus, has been sequenced. We previously used the mitochondrial genome to study the genetic relationships of Scorpaeniformes [12], which does not include the Platycephalidae family, although phylogenetic trees based on nuclear genes and partial mitochondrial gene sequences were constructed to analyze interspecies relationships with Scorpaeniformes in previous research. Nevertheless, the difference between whether flatheads or scorpionfishes are 'the most basal clade' of Scorpaeniformes was studied [13-15]. The markers of small fragments may not provide sufficient evidence to explain phylogenetic relationships. To research higher-level relationships among Scorpaeniformes, the complete mitogenome of one Platycephalidae species, Cociella crocodilus, was sequenced in our study and we analyzed the gene content and organization compared with other Scorpaeniformes species. In addition, the phylogenetic tree based on the thirteen PCG sequences was reconstructed by Maximum Likelihood (ML) and Bayesian inference (BI) methods to understand the higher phylogeny of Scorpaeniformes.

\section{Methods}

\subsection{Sampling and DNA Extraction}

A specimen of C. crocodilus was captured in the Pearl River estuary (N $21^{\circ} 45^{\prime}$, E $\left.133^{\circ} 36^{\prime}\right)$, China, in July 2016.The field study did not involve endangered or protected species, in accordance with the IUCN Red List. The research was approved by the Institutional Animal Care and Use Committee at Jinan University, with no ethical code associated. The experiments were conducted in accordance with international guidelines for the care and treatment of laboratory animals. The samples were identified according to morphological characteristics and were then conserved in 95\% ethanol and stored at $-80{ }^{\circ} \mathrm{C}$ until processing. Dorsal muscle tissue was removed to extract the total genomic DNA using the Animal Tissue Genomic DNA Extraction Kit (SangonBiotech, Shanghai, China) according to the manufacturer's instructions. The extracted DNA was used to amplify the complete mitogenome of C. crocodilus by polymerase chain reaction (PCR).

\subsection{Polymerase Chain Reaction Amplification and Sequencing}

To obtain the complete $C$. crocodilus mitogenome sequence, PCR amplification was performed with several primer pairs designed based on aligned mitogenome sequences of Chelidonichthys kumu (GenBank: KY379222) and Lepidotrigla microptera (GenBank: KY012348.1) (Table S1) [12]. All PCR reactions were conducted with LA Taq DNA polymerase using Premix LA Taq (Takara, Dalian, China) according to the following cycling conditions: beginning with an initial denaturation step at $95^{\circ} \mathrm{C}$ for $1 \mathrm{~min}$, followed by $35 \mathrm{cycles}$ of denaturation at $95^{\circ} \mathrm{C}$ for $20 \mathrm{~s}$, annealing at $55^{\circ} \mathrm{C}$ for $45 \mathrm{~s}$ and elongation at $72{ }^{\circ} \mathrm{C}$ for 1-5 min depending on the length of the segment. The sequences of the PCR-amplified products were determined on a 3730XL DNA Analyzer (Beijing Genomics Institute, Shenzhen China). 


\subsection{Sequence Analysis}

In order to obtain the final complete sequence, the obtained sequenced fragments were assembled through the program Seqman within the Lasergene software and then manually checked [16]. Sequence annotation was performed using NCBI BLAST (http://blast.ncbi.nlm.nih.gov/Blast) and the DNASTAR package (DNASTAR Inc, Madison, WI, USA). The tRNA genes were identified using the default search mode of the tRNAscan-SE program [17]. Secondary structures of tRNA genes and $\mathrm{O}_{\mathrm{L}}$ were inferred using the software RNAstructure [18] with vertebrate mitochondrial predictors. The Dual Organellar GenoMe Annotator (DOGMA) automated the annotation of two rRNA and 13 PCGs [19]. The codon usage of the protein-coding genes and the nucleotide composition were determined using MEGA 6.0 [20]. The tandem repeats in the control region were predicted using the Tandem Repeats Finder available online [21]. The formulas AT-skew $[(A-T) /(A+T)]$ and GC-skew $[(G-C) /(G+C)]$ were used to measure the nucleotide composition skewness [22]. The final mitogenome sequence of the C. crocodilus was submitted to the GenBank database under the accession number MH521260.1.

\subsection{Phylogenetic Analysis}

Based on 39 Scorpaeniformes mitogenomes available in the GenBank, phylogenetic analysis was performed (Table 1). Three outgroups taxa were assigned, i.e., Perciformes fishes (Percalates novemaculeata (NC_024850.1) and Siniperca knerii (NC_015987.1) [23,24]. The concatenated nucleotide sequence alignment was used in IQ-TREE and MrBayes v 3.2.4 to determine maximum likelihood (ML) and Bayesian inference (BI) for phylogenetic analysis [25,26]. All the sequences of the genes were aligned individually by ClustalX [27]. GTR+F+R6 was selected as the appropriate model for the nucleotide sequences by ModelFinder in IQ-TREE based on Akaike's information criterion (AIC) [25,28]. Four independent Markov chains were simultaneously used at 1,000,000 generations with sampling every 1000 generations for BI analyses. The first $25 \%$ were discarded as burn-in. The BI Tree was considered to be reached since the average standard deviation of the split frequencies was below 0.01 . ML analysis was carried out with 100 bootstrap replicates based on the default parameters. 
Table 1. Summary of the base composition and skewness of whole mitochondrial genomes and 13 protein-coding genes (PCGs) among 39 Scorpaeniformes species.

\begin{tabular}{|c|c|c|c|c|c|c|c|c|c|c|c|c|}
\hline \multirow{2}{*}{ Family } & \multirow{2}{*}{ Species } & \multirow{2}{*}{ Accession Number } & \multirow{2}{*}{ Size (bp) } & \multicolumn{7}{|c|}{ Whole Genome Composition } & \multicolumn{2}{|c|}{ PCGs } \\
\hline & & & & $\mathbf{A} \%$ & G\% & $\mathrm{T} \%$ & $\mathrm{C} \%$ & $\mathrm{~A}+\mathrm{T} \%$ & AT skew & GC skew & AT skew & GC skew \\
\hline Anoplopomatidae & Erilepis zonifer & AP017436.1 & 16,500 & 26.70 & 17.79 & 29.03 & 26.48 & 53.18 & 0.0041 & -0.2400 & -0.0965 & -0.2715 \\
\hline Anoplopomatidae & Anoplopoma fimbria & KP777542.1 & 16,507 & 26.07 & 18.34 & 29.58 & 26.01 & 52.08 & 0.0010 & -0.2346 & -0.0994 & -0.2701 \\
\hline Agonidae & Aspidophoroides olrikii & КT004434.1 & 17,200 & 27.30 & 16.90 & 27.28 & 28.49 & 55.80 & -0.0214 & -0.2350 & -0.1153 & -0.2662 \\
\hline Cottidae & Icelus spatula & КT004432.1 & 16,384 & 26.43 & 17.43 & 30.04 & 26.03 & 52.46 & 0.0078 & -0.2656 & -0.0987 & -0.2935 \\
\hline Cottidae & Trachidermus fasciatus & JX017305.1 & 16,536 & 26.33 & 18.13 & 30.07 & 25.47 & 51.80 & 0.0167 & -0.2478 & -0.0815 & -0.2750 \\
\hline Cottidae & Cottus poecilopus & EU332750.1 & 16,560 & 25.69 & 18.18 & 30.39 & 25.74 & 51.43 & -0.0011 & -0.2513 & -0.1040 & -0.2822 \\
\hline Cottidae & Cottus hangiongensis & NC_014851.1 & 16,598 & 25.48 & 18.22 & 30.40 & 25.87 & 51.36 & -0.0075 & -0.2506 & -0.1135 & -0.2840 \\
\hline Cottidae & Enophrys diceraus & NC_022147.1 & 16,976 & 27.53 & 16.65 & 28.64 & 27.19 & 54.71 & 0.0062 & -0.2648 & -0.0869 & -0.2987 \\
\hline Cottidae & Cottus reinii & AP004442.1 & 16,561 & 26.30 & 17.63 & 30.28 & 25.78 & 52.09 & 0.0100 & -0.2640 & -0.0919 & -0.2999 \\
\hline Cottidae & Mesocottus haitej & NC_022181.1 & 16,527 & 26.64 & 17.35 & 29.88 & 26.12 & 52.76 & 0.0099 & -0.2653 & -0.0853 & -0.2995 \\
\hline Cottidae & Cottus szanaga & KX762050.1 & 16,518 & 26.51 & 17.39 & 29.94 & 26.16 & 52.67 & 0.0067 & -0.2650 & -0.0853 & -0.3000 \\
\hline Cottidae & Cottus czerskii & NC_025242.1 & 16,534 & 26.40 & 17.47 & 30.07 & 26.07 & 52.47 & 0.0063 & -0.2651 & -0.0850 & -0.3130 \\
\hline Cottidae & Cottus dzungaricus & NC_024739.1 & 16,527 & 26.93 & 17.07 & 29.70 & 26.30 & 53.23 & 0.0119 & -0.2701 & -0.0822 & -0.3135 \\
\hline Hexagrammidae & Pleurogrammus monopterygius & NC_023475.1 & 16,575 & 27.05 & 17.15 & 28.68 & 27.12 & 54.17 & -0.0012 & -0.2517 & -0.0956 & -0.2913 \\
\hline Hexagrammidae & Hexagrammos lagocephalus & KP682334.1 & 16,505 & 26.98 & 17.26 & 29.48 & 26.29 & 53.27 & 0.0130 & -0.2615 & -0.0836 & -0.3002 \\
\hline Hexagrammidae & Hexagrammos otakii & AP017443.1 & 16,513 & 26.90 & 17.33 & 29.87 & 25.90 & 52.80 & 0.0189 & -0.2656 & -0.0727 & -0.3067 \\
\hline Hexagrammidae & Hexagrammos agrammus & AB763992.1 & 16,514 & 26.88 & 17.23 & 29.72 & 26.15 & 53.03 & 0.0137 & -0.2659 & -0.0839 & -0.3009 \\
\hline Peristediidae & Satyrichthys amiscus & AP004441.1 & 16,526 & 27.06 & 17.00 & 28.56 & 27.38 & 54.44 & -0.0058 & -0.2537 & -0.1030 & -0.2883 \\
\hline Platycephalidae & Platycephalus indicus & AP006783.1 & 16,542 & 27.32 & 16.99 & 30.12 & 25.57 & 52.88 & 0.0332 & -0.2787 & -0.0537 & -0.3143 \\
\hline Platycephalidae & Cociella crocodila & MH521260.1 & 17,314 & 29.14 & 15.91 & 27.76 & 27.19 & 56.33 & 0.0348 & -0.2713 & -0.0375 & -0.2911 \\
\hline Scorpaenidae & Pterois miles & NC_024746.1 & 16,497 & 27.40 & 18.26 & 28.74 & 25.60 & 53.00 & 0.0340 & -0.2229 & -0.0509 & -0.2420 \\
\hline Scorpaenidae & Scorpaenopsis cirrosa & NC_027735.1 & 16,966 & 27.91 & 17.71 & 28.02 & 26.35 & 54.27 & 0.0288 & -0.2254 & -0.0601 & -0.2448 \\
\hline Sebastidae & Sebastes oblongus & NC_024549.1 & 16,396 & 27.91 & 16.96 & 28.72 & 26.41 & 54.32 & 0.0276 & -0.2574 & -0.0595 & -0.2842 \\
\hline Sebastidae & Sebastes thompsoni & NC_027447.1 & 16,405 & 27.98 & 17.04 & 28.21 & 26.77 & 54.75 & 0.0222 & -0.2468 & -0.0677 & -0.2781 \\
\hline Sebastidae & Sebastes minor & NC_027444.1 & 16,408 & 27.79 & 17.33 & 27.63 & 27.25 & 55.04 & 0.0099 & -0.2292 & -0.0815 & -0.2609 \\
\hline Sebastidae & Sebastes trivittatus & NC_027446.1 & 16,409 & 27.86 & 17.09 & 28.37 & 26.67 & 54.54 & 0.0218 & -0.2480 & -0.0690 & -0.2789 \\
\hline Sebastidae & Sebastes taczanowskii & KJ525744.1 & 16,452 & 27.71 & 17.29 & 28.53 & 26.47 & 54.18 & 0.0229 & -0.2452 & -0.0709 & -0.2748 \\
\hline Sebastidae & Sebastes owstoni & KJ834063.1 & 16,465 & 27.71 & 17.30 & 28.41 & 26.57 & 54.28 & 0.0210 & -0.2430 & -0.0748 & -0.2723 \\
\hline Sebastidae & Sebates schlegeli & AY491978.1 & 16,525 & 27.47 & 17.45 & 28.74 & 26.34 & 53.80 & 0.0210 & -0.2444 & -0.0680 & -0.2742 \\
\hline Sebastidae & Sebastiscus marmoratus & AP005989.1 & 17,301 & 28.69 & 16.51 & 28.14 & 26.67 & 55.36 & 0.0364 & -0.2605 & -0.0592 & -0.2855 \\
\hline Sebastidae & Sebastes pachycephalus & KF836442.1 & 16,415 & 27.77 & 17.24 & 28.66 & 26.33 & 54.10 & 0.0266 & -0.2488 & -0.0635 & -0.2786 \\
\hline Sebastidae & Sebastes longispinis & KJ834061.1 & 16,445 & 27.91 & 17.12 & 28.31 & 26.66 & 54.57 & 0.0230 & -0.2462 & -0.0699 & -0.2713 \\
\hline Sebastidae & Sebastes steindachneri & NC_027445.1 & 16,450 & 27.36 & 17.54 & 28.01 & 27.09 & 54.46 & 0.0049 & -0.2298 & -0.0873 & -0.2587 \\
\hline Sebastidae & Sebastes hubbsi & KJ525745.1 & 16,453 & 27.86 & 17.20 & 28.28 & 26.66 & 54.52 & 0.0221 & -0.2436 & -0.0671 & -0.2714 \\
\hline Sebastidae & Sebastes vulpes & NC_027438.1 & 16,462 & 27.71 & 17.14 & 28.61 & 26.55 & 54.25 & 0.0214 & -0.2506 & -0.0706 & -0.2808 \\
\hline Sebastidae & Sebastes inermis & KF725093.1 & 16,504 & 27.77 & 17.13 & 28.34 & 26.76 & 54.53 & 0.0186 & -0.2466 & -0.0714 & -0.2735 \\
\hline Synanceiidae & Synanceia verrucosa & NC_026989.1 & 16,506 & 31.01 & 15.06 & 25.60 & 28.34 & 59.35 & 0.0451 & -0.2593 & -0.0286 & -0.2883 \\
\hline Triglidae & Chelidonichthys kumu & KY379222.1 & 16,495 & 26.63 & 17.04 & 31.13 & 25.20 & 51.83 & 0.0277 & -0.2925 & -0.0640 & -0.3351 \\
\hline Triglidae & Lepidotrigla microptera & KY012348.1 & 16,610 & 26.53 & 17.15 & 31.28 & 25.05 & 51.58 & 0.0286 & -0.2918 & -0.0666 & -0.3326 \\
\hline
\end{tabular}




\section{Results and Discussion}

\subsection{Mitogenome Organization, Structure and Skewness}

The complete mitogenome of $C$. crocodilus formed a closed circular molecule with a total length of 17,314 bp in size, which was the largest of all the sequenced Scorpaeniformes species available in the GenBank to date. The mitogenome contained 37 genes identical to other Scorpaeniformes species: two rRNA genes (12S rRNA and 16S rRNA), 22 tRNAs (one for each amino acid, two for Leucine and Serine), 13 PCGs (cox1-3, nad1-6, nad4L, atp6, atp8 and cytb) and two noncoding regions (control region $(\mathrm{CR})$ and $\mathrm{O}_{\mathrm{L}}$ ) (Figure $\mathrm{S} 1$ and Table 2). Except ND6 and eight tRNA genes (Gln, Ala, Asn, Cys, Tyr, Ser (UCN), Glu and Pro), which were distributed on the light strand (L-strand), most of the other mitochondrial genes were distributed on the heavy strand (H-strand). The mitogenome of $C$. crocodilus had a total overlap of $29 \mathrm{bp}$ (ranging from 1 to $10 \mathrm{bp}$ ) between genes at nine locations, among which atp8-atp6 (10 bp) and nad4L-nad4 (7 bp) often occurred in the Metazoa. A total of $162 \mathrm{bp}$ nucleotides ranged from 1 to $79 \mathrm{bp}$ in 15 spacers. The longest $79 \mathrm{bp}$ spacer was between tRNA ${ }^{\mathrm{L} 1}$ and nad1 (Table 2). The nucleotide composition of the C. crocodilus is as follows: $\mathrm{A}=29.14 \%, \mathrm{~T}=27.19 \%, \mathrm{G}=15.91 \%$ and $\mathrm{C}=27.76 \%$, which shows a high $\mathrm{A}+\mathrm{T}$ content of $56.3 \%$. The $\mathrm{A}+\mathrm{T}$ content is higher than most sequenced Scorpaeniformes species, such as Sebates schlegeli (53.8\%), Scorpaenopsis cirrosa (54.27\%), and Hexagrammos lagocephalus (53.27\%). The exception is Synanceia verrucosa (59.35\%). The fact that the $A+T$ content was higher than the G+C content is in accordance with the characteristics of the mitogenome of metazoan animals [29]. For the complete mitogenome sequence of Cociella crocodilus, the AT skew was positive (0.0348) and the GC skew was negative (-0.2713). Generally, the teleostean mitogenomes tend to have identical positive AT-skew and negative GC-skew. All of the GC skew was negative among Scorpaeniformes species and most of the AT skew was positive, apart from Satyrichthys amiscus (-0.0058), Pleurogrammus monopterygius (-0.0012), Cottus hangiongensis (-0.0011), and Cottus poecilopus $(-0.0075)[30,31]$.

Table 2. Organization constituents of the mitochondrial genome of Cociella crocodilus.

\begin{tabular}{|c|c|c|c|c|}
\hline Feature & Strand * & Position & Spacer $(+) /$ Overlap $(-)$ & Start/Stop Codon \\
\hline tRNA-Phe (F) & $\mathrm{H}$ & $1-67$ & 0 & \\
\hline 12S rRNA & $\mathrm{H}$ & 68-1088 & 0 & \\
\hline tRNA-Val (V) & $\mathrm{H}$ & $1089-1160$ & -2 & \\
\hline $16 \mathrm{~S}$ rRNA & $\mathrm{H}$ & $1161-2873$ & 79 & \\
\hline tRNA-Leu (L1) & $\mathrm{H}$ & 2872-2947 & 3 & \\
\hline nad1 & $\mathrm{H}$ & $3027-4001$ & -1 & ATG/TAA \\
\hline tRNA-Ile (I) & $\mathrm{H}$ & $4005-4074$ & 23 & \\
\hline tRNA-Gln (Q) & $\mathrm{L}$ & $4074-4144$ & 1 & \\
\hline tRNA-Met (M) & $\mathrm{H}$ & $4168-4237$ & 6 & \\
\hline nad 2 & $\mathrm{H}$ & $4239-5288$ & 0 & ATG/TAA \\
\hline tRNA-Trp (W) & $\mathrm{H}$ & $5295-5366$ & 1 & \\
\hline tRNA-Ala (A) & $\mathrm{L}$ & $5367-5435$ & 30 & \\
\hline tRNA-Asn (N) & $\mathrm{L}$ & $5437-5509$ & 0 & \\
\hline tRNA-Cys (C) & $\mathrm{L}$ & $5540-5607$ & 1 & \\
\hline tRNA-Tyr (Y) & $\mathrm{L}$ & $5608-5675$ & 0 & \\
\hline $\operatorname{cox} 1$ & $\mathrm{H}$ & $5677-7227$ & 3 & GTG/TAA \\
\hline tRNA-Ser (S1) & $\mathrm{L}$ & $7228-7298$ & 5 & \\
\hline tRNA-Asp (D) & $\mathrm{H}$ & $7302-7374$ & 0 & \\
\hline $\cos 2$ & $\mathrm{H}$ & $7380-8070$ & 1 & ATG/T \\
\hline tRNA-Lys (K) & $\mathrm{H}$ & $8071-8145$ & -10 & \\
\hline atp 8 & $\mathrm{H}$ & $8147-8311$ & -1 & ATG/TAA \\
\hline $\operatorname{atp} 6$ & $\mathrm{H}$ & $8302-8985$ & -1 & ATG/TAA \\
\hline $\operatorname{cox} 3$ & $\mathrm{H}$ & $8985-9770$ & 0 & ATG/TAA \\
\hline tRNA-Gly (G) & $\mathrm{H}$ & 9770-9841 & -2 & \\
\hline nad3 & $\mathrm{H}$ & $9842-10,192$ & 0 & ATG/TAG \\
\hline tRNA-Arg (R) & $\mathrm{H}$ & $10,191-10,259$ & -7 & \\
\hline nad4l & $\mathrm{H}$ & $10,260-10,556$ & 0 & ATG/TAA \\
\hline
\end{tabular}


Table 2. Cont.

\begin{tabular}{ccccc}
\hline Feature & Strand * & Position & Spacer (+)/Overlap (-) & Start/Stop Codon \\
\hline nad4 & $\mathrm{H}$ & $10,550-11,930$ & -7 & ATG/T \\
tRNA-His (H) & $\mathrm{H}$ & $11,931-11,999$ & 0 & \\
tRNA-Ser (S1) & $\mathrm{H}$ & $12,002-12,069$ & 2 & \\
tRNA-Leu (L1) & $\mathrm{H}$ & $12,074-12,146$ & 4 & ATG/TAA \\
nad5 & $\mathrm{H}$ & $12,147-13,985$ & 0 & ATG/TAG \\
nad6 & $\mathrm{L}$ & $13,982-14,503$ & -4 & \\
tRNAGlu (E) & $\mathrm{L}$ & $14,505-14,573$ & 1 & ATG/T \\
cytb & $\mathrm{H}$ & $14,576-15,725$ & 2 & \\
tRNA-Thr (T) & $\mathrm{H}$ & $15,726-15,797$ & 0 & \\
tRNA-Pro (P) & $\mathrm{L}$ & $15,797-15,867$ & -1 & \\
Control region & $\mathrm{H}$ & $15,868-17,314$ & 0 &
\end{tabular}

\subsection{Protein-Coding Genes}

The complete mitogenome of C. crocodilus had 13 PCGs with a total length of 11,445 bp, 12 of which utilize ATG for the start codon, whereas cox1 utilizes GTG. In teleost mitogenomes, initiator codons are often used selectively (e.g., cox1 of the whiting, Merlangius merlangus; cox 1 of the haddock, Melanogrammus aeglefinus; and cox1 and nad 41 of the Globose Head Whiptail, Cetonurus globiceps) [32,33]. Eight of the 13 PCGs (nad1, nad2, cox1, atp8, atp6, cox3, nad4l, and nad5) used the typical stop codon TAA. The two genes nad 3 and nad 6 were terminated with TAG. The incomplete termination codon T was used by cox2, nad4, and cytb (Table 2). Such incomplete termination codons were due to the 3 ' end of the mRNA appearing to have posttranscriptional polyadenylation [34]. Except for the AGA and AGG termination codons, the total number of codons in the PCGs of C. crocodilus was 3,804, among which three amino acids (Leu1, 513, Ala, 353, and Thr, 302) were the most frequent (Figure 1 and Table S2). In addition to the three genes of C. crocodilus, cox2, nad4 and nad5, most of the AT skew was negative. Most of the GC skew values were slightly negative, except for nad6, indicating that there were more Ts and Cs in most PCGs, which is consistent with previous research (Figure 2).

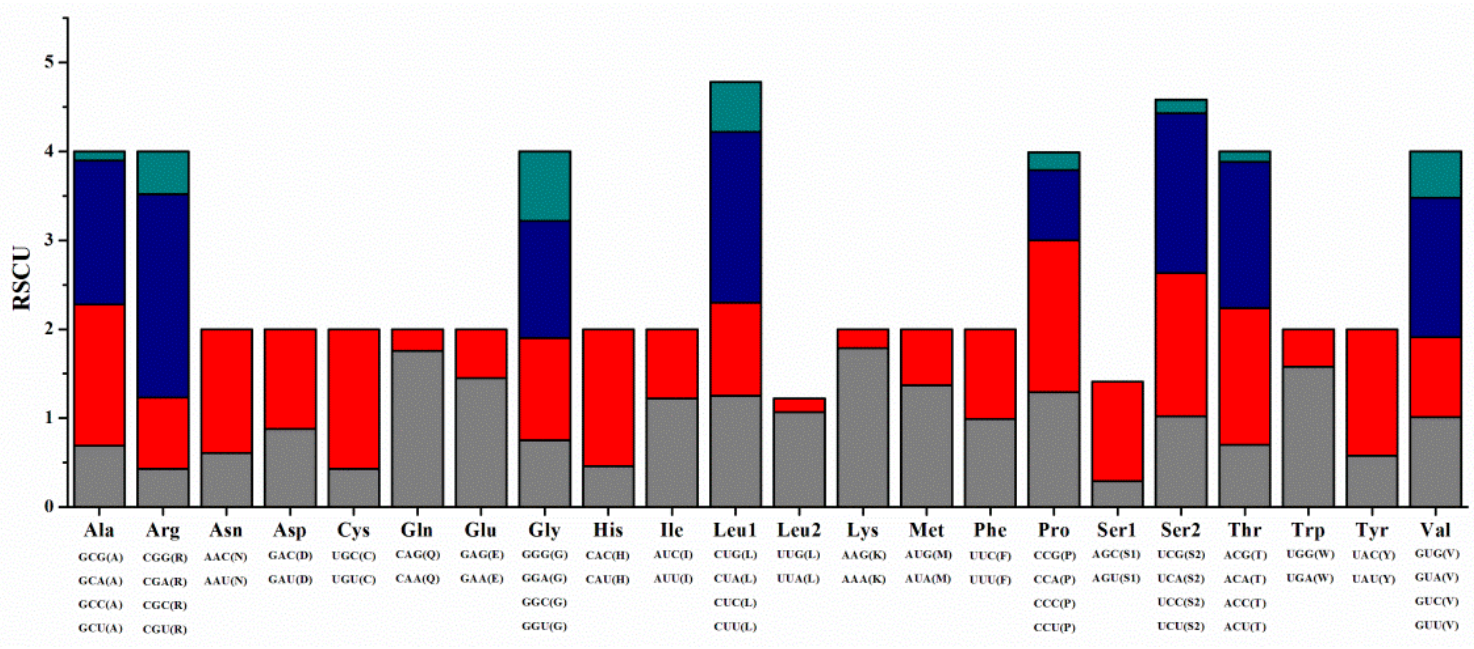

Figure 1. Relative synonymous codon usage (RSCU) of the C. crocodilus mitogenome.

\subsection{Transfer RNA Genes and Ribosomal RNA Genes}

There were $22 \mathrm{tRNA}$ genes ranging from $67 \mathrm{bp}(\operatorname{trnP})$ to $76 \mathrm{bp}$ (trnL1) identified in the C. crocodilus mitogenome. Among them, 14 tRNA genes were encoded on the $\mathrm{H}$-strand, and the other eight tRNA genes were coded by the L-strand (Table 2). Most of the tRNAs were folded into an ordinary cloverleaf secondary structure (Figure S2), except trnS2 (AUN), which lacked a DHU stem. This phenomenon is 
identical to other mitogenomes of teleost fishes, including the Scorpaeniformes species [12,35]. The standard structure of the amino acid acceptor stem was $7 \mathrm{bp}$, while trnaV, trnF, and trnaL1 (UUR) were 9 bp. Further, there were 24 base-pair mismatches present in the tRNA secondary structures, all of which formed a weak bond (G-U pairs). The compositions of the complete sequences of all $22 \mathrm{tRNAs}$ showed both slightly positive AT skew (0.0136) and GC skew (0.0473), indicating that tRNAs biased toward As and Gs. The 12S and 16S rRNA genes were 1,021 bp and 1,713 bp in length, respectively, and similarly, the AT skew (0.0763 and 0.2227) was slightly positive and the GC skew $(-0.1952$ and -0.1064 ) was negative. They were situated between trnF and trnL1 and there is a trnV between rRNAs similar to other vertebrate mitogenomes to date [36-38].

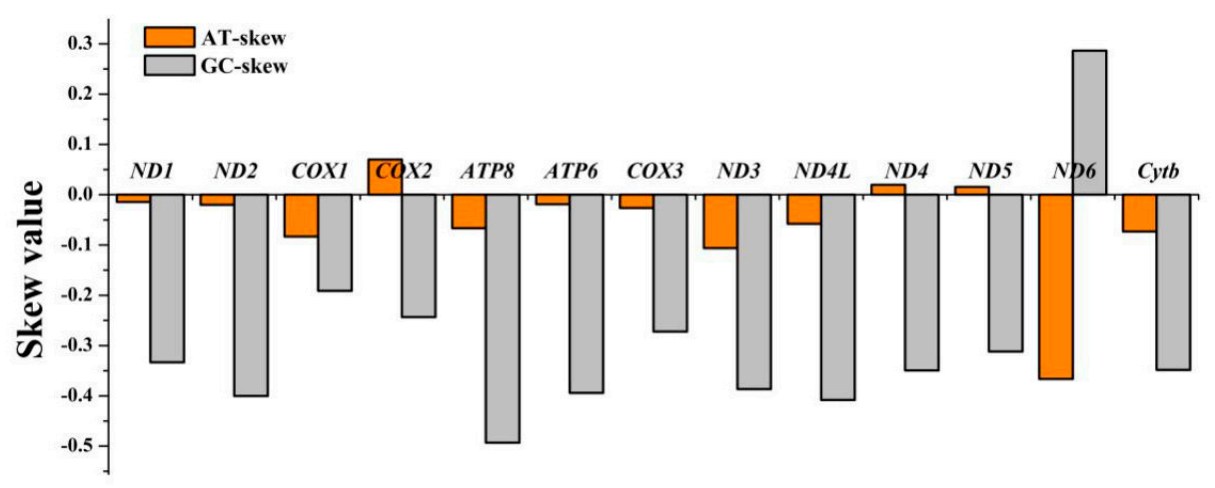

Figure 2. The AT skew and GC skew in the PCGs of the C. crocodilus mitogenome.

\subsection{Noncoding Regions}

There were two long noncoding regions in the mitogenome of C. crocodilus, $\mathrm{O}_{\mathrm{L}}$ and $\mathrm{CR}$, which were closely related to the initiation of the replication and transcription of the mitogenome [39,40]. Located between trnN and trnC with a length of $30 \mathrm{bp}$, the relatively short gene $\mathrm{O}_{\mathrm{L}}$ was folded into a hairpin secondary structure (Figure S3). The CR was the longest noncoding region and extended over $1447 \mathrm{bp}$ between trnP and trnF, with a 68.76\% A + T content, which is the highest among Scorpaeniformes species to date. Similarly to other teleost fish, there were several conserved sequence blocks (CSBs) identified in CR, which were shown to play indispensable roles in mitochondrial metabolism [41]. The central conserved domain contained blocks CSB-D, -E and -F, while the typical conserved sequence block region involved blocks CSB-1, CSB-2 and CSB-3 (Figure S4). Consistent with other Scorpaeniformes species, the conserved motifs ATGTA and its complement TACAT as the recognition sites are commonly found in the CR of teleosts. In addition, eight concatenated repeats in C. crocodilus were confirmed with the Tandem Repeats Finder program [21]. This phenomenon occurs only in Enophrys diceraus and Sebastiscus marmoratus, but never in other Scorpaeniformes species [42,43]. These tandem repeats may be one reason why the C. crocodilus mitogenome was bigger than in other sequenced Scorpaeniformes species.

\subsection{Phylogenetic Relationships}

To determine the phylogenetic position of C. crocodilus, 39 Scorpaeniformes species' mitogenomes were obtained from the GenBank and the mitogenomes of Perciformes fishes (P. novemaculeata (NC_024850.1) and S. knerii (NC_015987.1) were used for outgroups (Figure 3). Phylogenetic trees inferred from the ML and BI methods were constructed for the nucleotide sequences of 13 PCGs. The results clearly indicate that flatheads, scorpionfishes and rockfishes together comprised Scorpaeniformes as a paraphyletic group. The phylogenetic trees revealed three strongly supported clades: (I) Synanceiidae and Platycephalidae, (II) Scorpaenidae and Sebastidae, and (III) Anoplopomatidae, Agonidae, Triglidae, Peristediidae, Hexagrammidae and Cottidae. The best supported phylogenetic relationships of Scorpaeniformes are as follows: (Synanceiidae + (Platycephalidae + ((Scorpaenidae + Sebastidae $)+(($ Triglidae + Peristediidae $)+($ Agonidae $+($ Hexagrammidae + (Anoplopomatidae 
+ Cottidae))))))). There was a conflict with our work based on complete mitogenomes [12]. In a previous study, Synanceiidae was as a sister to Scorpaenidae + Sebastidae. The phylogenetic analysis results were similar to earlier studies (although only Synanceiidae, Scorpaenidae and Sebastidae were available) [44]. Based on the results of the current study, Synanceiidae was proposed to be one of the most basal taxa in the order of Scorpaeniformes after adding new taxa (Anoplopomatidae, Agonidae and Platycephalidae) to the phylogenetic analysis. As the only sequenced mitogenome to date, the Synanceiidae family requires further phylogenetic research. C. crocodilus, within Platycephalidae, which branches into an independent sub-branch, shares a close ancestry with $P$. indicus. The topology data obtained in this study indicates that the flatheads were more basal than scorpionfishes among Scorpaeniformes, which is not consistent with previous studies involving phylogenetic analysis on the basis of segmental mitogenomes (16S rRNA) and nuclear genes (rag1, rag2, and $r h$ ) [13]. Whether the difference in the phylogenetic analysis is due to introgression, hybridization and lineage sorting is unknown. However, some phylogenetic results also showed that flatheads were relatively basal species based on a modified time-calibrated model [14,15]. Additional research should be conducted to discover other un-sequenced families and employ other molecular datasets to elucidate phylogenetic relationships among Scorpaeniformes species.

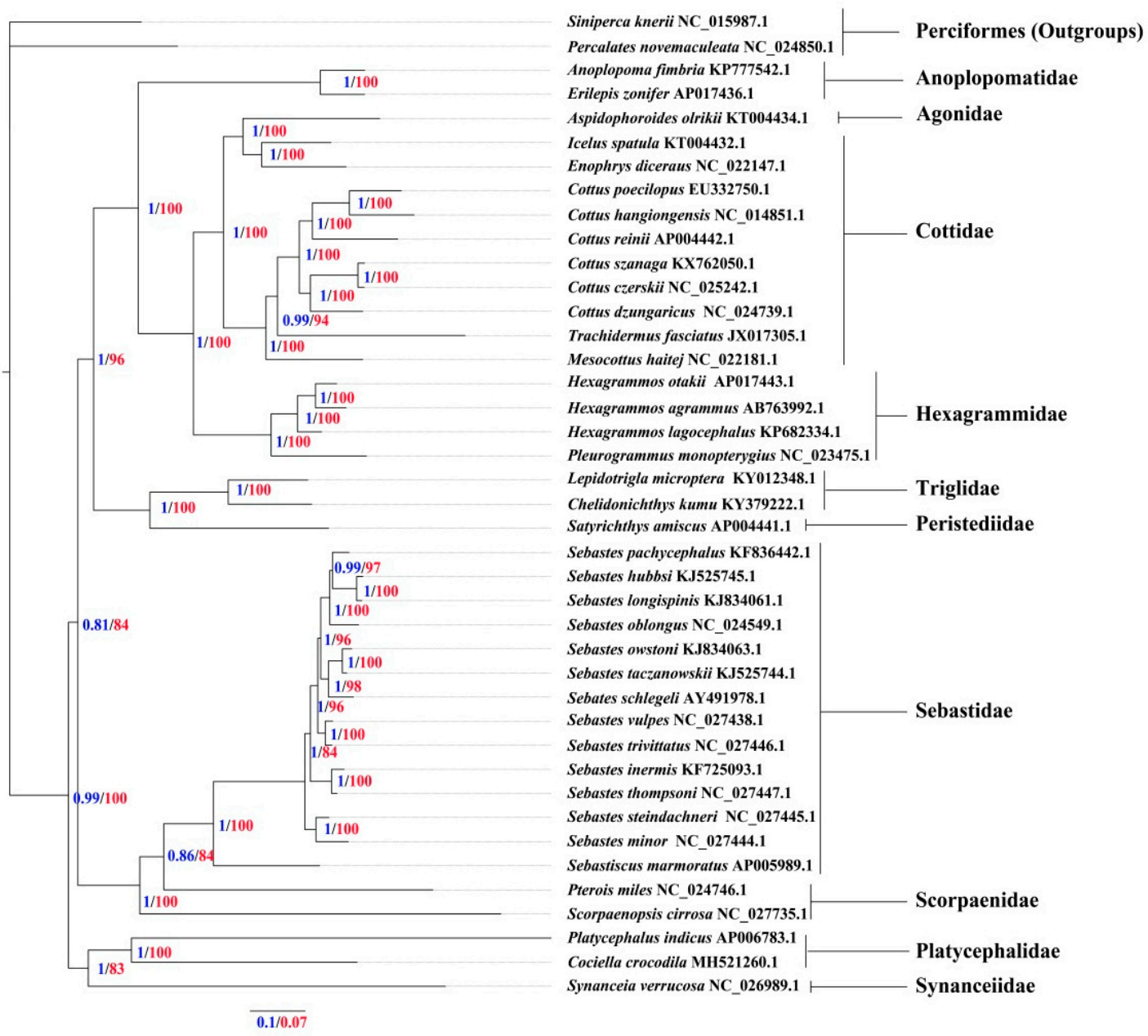

Figure 3. Phylogenetic tree based on the nucleotide sequences of the 13 PCGs, using Bayesian inference (BI) and maximum likelihood (ML) methods, among Scorpaeniformes species. Perciformes fishes (P. novemaculeata (NC_024850.1) and S. knerii (NC_015987.1)) were used as outgroups. Numbers above the branches refer to Bayesian posterior probability values (blue numbers) and ML bootstrap values (red numbers). 
Supplementary Materials: The following are available online at http://www.mdpi.com/2073-4425/10/7/533/s1, Figure S1: Organization of the complete mitochondrial genome of C. crocodilus, Figure S2: Predicted secondary structures of 22 tRNA genes in the C. crocodilus mitogenome. Figure S3: The putative secondary hairpin structural features of the $\mathrm{O}_{\mathrm{L}}$ in the mitogenome of $C$. crocodilus, Figure S4: The structure of the control region in the mitogenome of $C$. crocodilus, Table S1: Primer pairs used for PCR amplification of $C$. crocodilus mitogenome, Table S2: Codon number and RSCU in C. crocodilus mitochondrial PCGs.

Author Contributions: Conceptualization, L.C., J.C. and S.L.; data curation, L.C., R.C. and Y.D.; formal analysis, L.C. and R.C.; funding acquisition, J.C. and S.L.; investigation, X.G. and J.C.; methodology, X.G.; resources, X.G. and J.C.; supervision, S.L.; validation, Y.D.; writing—original draft, L.C., R.C. and Y.D.; writing—review \& editing, J.C. and S.L.

Funding: This work was supported by the National Natural Science Foundation of China (No. 41806127) and the Natural Science Foundation of Guangdong Province (No. 2018A030313956).

Conflicts of Interest: The authors declare no conflict of interest.

\section{References}

1. Keenan, C.P. Phylogeny of Australian species of flatheads (Teleostei, Platycephalidae) as determined by allozyme electrophoresis. J. Fish Biol. 2010, 39, 237-249. [CrossRef]

2. Dulčić, J.; Pallaoro, A.; Dragičević, B.; Stagličić-Radica, N. First record of dwarf flathead Elates ransonnetii (Platycephalidae) in the Adriatic Sea. Cybium 2010, 34, 222-223.

3. Imamura, H. Phylogeny of the family platycephalidae and related taxa (Pisces: Scorpaeniformes). Species Divers. 1996, 1, 123-233. [CrossRef]

4. Sriramachandra Murty, V.; Manikyam, Y. Taxonomic Revision of the Flatheads (Platycephalidae: Pisces) of India; Zoological Survey of India: Kolkata, India, 2007.

5. Imamura, H.; Sakashita, M. Redescription of a rare flathead, Onigocia grandisquama (Regan, 1908) (Scorpaeniformes: Platycephalidae). Ichthyol. Res. 1997, 44, 119-124. [CrossRef]

6. Boore, J.L. Animal mitochondrial genomes. Nucleic Acids Res. 1999, 27, 1767-1780. [CrossRef]

7. Cameron, S.L. Insect mitochondrial genomics: Implications for evolution and phylogeny. Annu. Rev. Entomol. 2014, 59, 95-117. [CrossRef]

8. Simon, C.; Buckley, T.R.; Frati, F.; Stewart, J.B.; Beckenbach, A.T. Incorporating molecular evolution into phylogenetic analysis, and a new compilation of conserved polymerase chain reaction primers for animal mitochondrial DNA. Annu. Rev. Ecol. Evol. Syst. 2006, 37, 545-579. [CrossRef]

9. Miya, M.; Kawaguchi, A.; Nishida, M. Mitogenomic exploration of higher teleostean phylogenies: A case study for moderate-scale evolutionary genomics with 38 newly determined complete mitochondrial DNA sequences. Mol. Biol. Evol. 2001, 18, 1993-2009. [CrossRef]

10. Boore, J.L.; Lavrov, D.V.; Brown, W.M. Gene translocation links insects and crustaceans. Nature 1998, 392, 667-668. [CrossRef]

11. Dowton, M.; Castro, L.R.; Austin, A.D. Mitochondrial gene rearrangements as phylogenetic characters in the invertebrates: The examination of genome 'morphology'. Invertebr. Syst. 2002, 16, 345-356. [CrossRef]

12. Cui, L.; Dong, Y.; Liu, F.; Gao, X.; Zhang, H.; Li, L.; Cen, J.; Lu, S. The first two complete mitochondrial genomes for the family Triglidae and implications for the higher phylogeny of Scorpaeniformes. Sci. Rep. 2017, 7, 1553. [CrossRef] [PubMed]

13. Betancur, R.R.; Broughton, R.E.; Wiley, E.O.; Carpenter, K.; Ortí, G. The tree of life and a new classification of bony fishes. PLoS Curr. 2013, 5, 1001550. [CrossRef] [PubMed]

14. Rabosky, D.L.; Chang, J.; Title, P.O.; Cowman, P.F.; Sallan, L.; Friedman, M.; Kaschner, K.; Garilao, C.; Near, T.J.; Coll, M.; et al. An inverse latitudinal gradient in speciation rate for marine fishes. Nature 2018, 559, 392-395. [CrossRef] [PubMed]

15. Betancur, R.R.; Wiley, E.O.; Arratia, G.; Acero, A.; Bailly, N.; Miya, M.; Lecointre, G.; Ortí, G. Phylogenetic classification of bony fishes. BMC Evol. Biol. 2017, 17, 162. [CrossRef] [PubMed]

16. Swindell, S.R.; Plasterer, T.N. SEQMAN. Contig assembly. Methods Mol Biol. 1997, 70, 75-89. [CrossRef] [PubMed]

17. Lowe, T.M.; Eddy, S.R. tRNAscan-SE: A program for improved detection of transfer RNA genes in genomic sequence. Nucleic Acids Res. 1997, 25, 955-964. [CrossRef] [PubMed] 
18. Mathews, D.H. Using the RNAstructure software package to predict conserved RNA structures. Curr. Protoc. Bioinform. 2014, 46, 12.14.11-12.14.22. [CrossRef]

19. Wyman, S.K.; Jansen, R.K.; Boore, J.L. Automatic annotation of organellar genomes with DOGMA. Bioinformatics 2004, 20, 3252-3255. [CrossRef]

20. Tamura, K.; Stecher, G.; Peterson, D.; Filipski, A.; Kumar, S. MEGA6: Molecular evolutionary genetics analysis version 6.0. Mol. Biol. Evol. 2013, 30, 2725-2729. [CrossRef]

21. Benson, G. Tandem repeats finder: A program to analyze DNA sequences. Nucleic Acids Res. 1999, 27, 573-580. [CrossRef]

22. Perna, N.T.; Kocher, T.D. Patterns of nucleotide composition at fourfold degenerate sites of animal mitochondrial genomes. J. Mol. Evol. 1995, 41, 353-358. [CrossRef] [PubMed]

23. Chen, D.X.; Chu, W.Y.; Liu, X.L.; Nong, X.X.; Li, Y.L.; Du, S.J.; Zhang, J.S. Phylogenetic studies of three sinipercid fishes (Perciformes: Sinipercidae) based on complete mitochondrial DNA sequences. Mitochondrial Dna 2012, 23, 70. [CrossRef] [PubMed]

24. Lavoué, S.; Nakayama, K.; Jerry, D.R.; Yamanoue, Y.; Yagishita, N.; Suzuki, N.; Nishida, M.; Miya, M. Mitogenomic phylogeny of the Percichthyidae and Centrarchiformes (Percomorphaceae): Comparison with recent nuclear gene-based studies and simultaneous analysis. Gene 2014, 549, 46-57. [CrossRef] [PubMed]

25. Lam-Tung, N.; Schmidt, H.A.; Arndt, V.H.; Bui Quang, M. IQ-TREE: A fast and effective stochastic algorithm for estimating maximum-likelihood phylogenies. Mol. Biol. Evol. 2015, 32, 268-274.

26. Ronquist, F.; Teslenko, M.; Mark, P.V.D.; Ayres, D.L.; Darling, A.; Höhna, S.; Larget, B.; Liu, L.; Suchard, M.A.; Huelsenbeck, J.P. MrBayes 3.2: Efficient bayesian phylogenetic inference and model choice across a large model space. Syst. Biol. 2012, 61, 539-542. [CrossRef] [PubMed]

27. Thompson, J.D.; Gibson, T.J.; Higgins, D.G. Multiple sequence alignment using ClustalW and ClustalX. Curr. Protoc. Bioinform. 2002. [CrossRef] [PubMed]

28. MrModeltest, V2, program distributed by the author; Nylander, J.A.A., Evolutionary Biology Centre at Uppsala University; Science Open; Berlin. 2004.

29. Asakawa, S.; Kumazawa, Y.; Araki, T.; Himeno, H.; Miura, K.; Watanabe, K. Strand-specific nucleotide composition bias in echinoderm and vertebrate mitochondrial genomes. J. Mol. Evol. 1991, 32, 511-520. [CrossRef]

30. Miya, M.; Takeshima, H.; Endo, H.; Ishiguro, N.B.; Inoue, J.G.; Mukai, T.; Shirai, S.M. Major patterns of higher teleostean phylogenies: A new perspective based on 100 complete mitochondrial DNA sequences. Mol. Phylogenetics Evol. 2003, 26, 121-138. [CrossRef]

31. Hwang, D.S.; Byeon, H.K.; Lee, J.S. Complete mitochondrial genome of the freshwater sculpin Cottus hangiongensis (Scorpaeniformes, Cottidae). Mitochondrial Dna 2013, 24, 490-491. [CrossRef]

32. Shi, X.; Peng, T.; Lin, R.; Huang, D.; Wang, J. Characterization of the complete mitochondrial genome sequence of the globose head whiptail Cetonurus globiceps (Gadiformes: Macrouridae) and its phylogenetic analysis. PloS ONE 2016, 11, e0153666. [CrossRef]

33. Roques, S.; Fox, C.J.; Villasana, M.I.; Rico, C. The complete mitochondrial genome of the whiting, Merlangius merlangus and the haddock, Melanogrammus aeglefinus: A detailed genomic comparison among closely related species of the Gadidae family. Gene 2006, 383, 12-23. [CrossRef] [PubMed]

34. Ojala, D.; Montoya, J.; Attardi, G. tRNA punctuation model of RNA processing in human mitochondrial. Nature 1981, 290, 470-474. [CrossRef] [PubMed]

35. Lavrov, D.V.; Brown, W.M.; Boore, J.L. A novel type of RNA editing occurs in the mitochondrial tRNAs of the centipede Lithobius forficatus. Proc. Natl. Acad. Sci. USA 2000, 97, 13738-13742. [CrossRef] [PubMed]

36. Niu, S.; Liu, Y.; Qin, C.; Wang, X.; Wu, R. The complete mitochondrial genome and phylogenetic analysis of (Perciformes, Moronidae). Mitochondrial Dna 2015, 69, 1-3. [CrossRef] [PubMed]

37. Chou, C.E.; Wang, F.Y.; Chang, S.K.; Chang, H.W. Complete mitogenome of three flyingfishes Cheilopogon unicolor, Cheilopogon arcticeps and Cheilopogon atrisignis (Teleostei: Exocoetidae). Mitochondrial Dna Part B Resour. 2016, 1, 134-135. [CrossRef]

38. Li, Y.; Lu, J.; Wang, Z. Complete mitochondrial genome of Lasiopodomys mandarinus mandarinus (Arvicolinae, Rodentia). Mitochondrial Dna A Dna Mapp. Seq. Anal. 2016, 27, 1459-1460. [CrossRef] [PubMed]

39. Zhang, D.X.; Hewitt, G.M. Insect mitochondrial control region: A review of its structure, evolution and usefulness in evolutionary studies. Biochem. Syst. Ecol. 1997, 25, 99-120. [CrossRef] 
40. Fernã, N.-S.P.; Enriquez, J.A.; Montoya, J. Replication and transcription of mammalian mitochondrial DNA. Exp. Physiol. 2010, 88, 41-56. [CrossRef]

41. Lee, W.J.; Conroy, J.; Howell, W.H.; Kocher, T.D. Structure and evolution of teleost mitochondrial control regions. J. Mol. Evol. 1995, 41, 54-66. [CrossRef]

42. Li, A.; Munehara, H. Complete mitochondrial genome of the Antlered sculpin Enophrys diceraus (Scorpaeniformes, Cottidae). Mitochondrial Dna 2013, 26, 125-126. [CrossRef]

43. Xu, T.J.; Cheng, Y.Z.; Liu, X.Z.; Shi, G.; Wang, R.X. The complete mitochondrial genome of the marbled rockfish Sebastiscus marmoratus (Scorpaeniformes, Scorpaenidae): Genome characterization and phylogenetic considerations. Mol. Biol. 2011, 45, 392-403. [CrossRef]

44. Wang, Q.; Wang, J.; Luo, J.; Chen, G. The complete mitochondrial genome of the Synanceia verrucosa (Scorpaeniformes: Synanceiidae). Mitochondrial Dna A Dna Mapp. Seq. Anal. 2016, 27, 4234-4235. [CrossRef] [PubMed]

(C) 2019 by the authors. Licensee MDPI, Basel, Switzerland. This article is an open access article distributed under the terms and conditions of the Creative Commons Attribution (CC BY) license (http://creativecommons.org/licenses/by/4.0/). 